\title{
Organic carbon stocks and stock changes of forest biomass in Belgium derived from forest inventory data in a spatially explicit approach
}

\author{
Suzanna LetTens ${ }^{1 *}$, Jos VAN OrShOven ${ }^{2}$, Dominique PERrin ${ }^{3}$, Bas VAN WeSEMAeL ${ }^{4}$, Bart MUYS $^{2}$ \\ ${ }^{1}$ Research Institute for Nature and Forest, Gaverstraat 4, B-9500 Geraardsbergen, Belgium \\ ${ }^{2}$ Department of Land Management and Economics, Katholieke Universiteit Leuven, Celestijnenlaan 200E, B-3001 Leuven, Belgium \\ ${ }^{3}$ Plant Biology Unit, Gembloux Agricultural Sciences University, Passage des Déportés 2, B-5030 Gembloux, Belgium \\ ${ }^{4}$ Department of Geography, Université Catholique de Louvain, Bât. Mercator, Place Pasteur 3, B-1348 Louvain-la-Neuve, Belgium
}

(Received 12 November 2007; accepted 9 May 2008)

\begin{abstract}
-
- Carbon sequestration in forest ecosystems is an important though still uncertain process in the global greenhouse gas balance.

- We computed biomass organic carbon (BOC) stocks of spatially explicit forested landscape units (LSU) in Belgium based on data collected in the regional forest inventories of 1984 (Wallonia region only) and 2000 (Wallonia and Flanders). C stock changes between 1984 and 2000 were estimated for Wallonia.

- The total BOC pool stored in Belgian forests in 2000 amounts to $57.8 \mathrm{Mt} \mathrm{C}$ in $6222 \mathrm{~km}^{2}$, or $10.0 \mathrm{~kg} \mathrm{C} \mathrm{m}^{-2}$ in broadleaf, $9.5 \mathrm{~kg} \mathrm{C} \mathrm{m}-2$ in coniferous and $8.7 \mathrm{~kg} \mathrm{C} \mathrm{m}^{-2}$ in mixed forest. Based on previous soil organic carbon (SOC) analysis for the same LSU, BOC and SOC stock per LSU appeared only weakly correlated. The total BOC sequestration between 1984 and 2000 equals $5.7 \mathrm{Mt} \mathrm{C}$ over an area of $5107 \mathrm{~km}^{2}$, resulting in a flux of $0.07 \mathrm{~kg}$ $\mathrm{C} \mathrm{m}^{-2} \mathrm{y}^{-1}$. The BOC content of broadleaf forest in Wallonia increased with 6\%, of coniferous forest with $32 \%$ and of mixed forest with $11 \%$.

- The observed regional differences in BOC stocks and in BOC sequestration rates are explained by the forest age-class distribution and site productivity. The strength of the spatially explicit approach lies in the fact that BOC and SOC data originating from diverse sampling strategies can be combined for spatial or temporal comparison of $\mathrm{C}$ stocks.
\end{abstract}

forest inventory / Belgium / forest biomass / soil / carbon sequestration

Résumé - Évolution des stocks de carbone dans la biomasse des forêts belges entre 1984 et 2000.

- La séquestration du carbone par les écosystèmes forestiers constitue un processus important dans le bilan global des gaz à effet de serre, mais il subsiste des incertitudes dans sa compréhension.

- Nous avons calculé les stocks de carbone dans la biomasse («Biomass organic carbon » ou BOC) au sein d’unités spatiales de paysage («Landscape units » ou LSU) en Belgique, sur base des données collectées dans le cadre des inventaires forestiers régionaux de 1984 (Wallonie seulement) et 2000 (Wallonie et Flandres). Les variations des stocks de carbone ont été estimées entre 1984 et 2000 pour la Région wallonne uniquement.

- Le stock de BOC sur l'ensemble des forêts belges est de $57.8 \mathrm{Mt} \mathrm{C}$ en 2000 sur $6222 \mathrm{~km}^{2}$, soit $10.0 \mathrm{~kg} \mathrm{C} \mathrm{m}{ }^{-2}$ en forêt décidue, $9.5 \mathrm{~kg} \mathrm{C}^{-2}$ en forêt de conifères et $8.7 \mathrm{~kg} \mathrm{C} \mathrm{m}^{-2}$ en forêt mixte. Basé sur une précédente étude du carbone organique dans le sol («Soil organic carbon » ou SOC) pour les mêmes LSU, il apparaît que les quantités de BOC et de SOC par LSU sont faiblement corrélées. Le flux total de BOC observé entre 1984 et 2000 représente un gain de $5.7 \mathrm{Mt} \mathrm{C}$ pour une surface de $5107 \mathrm{~km}^{2}$, soit un flux de $0.07 \mathrm{~kg} \mathrm{C} \mathrm{m}^{-2} \mathrm{an}^{-1}$. Les variations de BOC sont de $6 \%$ en forêt décidue, $32 \%$ en résineux et $11 \%$ en peuplements mixtes.

- Les variations régionales de stocks et de flux de BOC sont expliquées par la distribution différente des classes d'âges des peuplements et par la productivité spécifique des sites. L'approche spatiale détaillée permet la combinaison de données de BOC et SOC issues de diverses stratégies d'échantillonnage afin de calculer les variations spatiales et temporelles des stocks de carbone.

inventaire forestier / Belgique / biomasse / sol / séquestration de carbone

\section{INTRODUCTION}

Several studies suggest that terrestrial ecosystems have sequestered C during recent years (e.g. de Vries et al., 2003; Houghton, 2003; Janssens et al., 2003; Liski et al., 2002, Nabuurs et al., 2003). The capacity of terrestrial ecosystems to store $\mathrm{C}$ is an important process in view of the obligations posed by the Kyoto Protocol (Valentini et al., 2000). Although the cause and spatial distribution of this terrestrial $\mathrm{C}$ uptake is sub-

*Corresponding author: suzanna.lettens@inbo.be ject of ongoing debate, the fact that part of the $\mathrm{C}$ sequestration occurs in forests is generally accepted (Nabuurs et al., 2003; Schimel et al., 2000). Forests constitute an important carbon stock at the global scale (Grace, 2004; Houghton, 2003; IPCC, 2000), part of which is located in the soil as more or less stable humus and litter and part exists in living biomass, mainly in trees. These pools may be influenced by human induced management changes, such as increasing rotation length, or by non-human induced factors, such as $\mathrm{N}$ deposition or $\mathrm{CO}_{2}$ fertilization (IPCC, 2000; Nabuurs and Mohren, 1993; Prentice et al., 2001). Spatially explicit knowledge of recent and past C 
stocks in forests will improve our understanding of the effect of human and non-human induced changes on forest $\mathrm{C}$ fluxes. This study presents a spatially explicit estimation of biomass organic carbon (BOC) stocks in Belgian forests for the years 1984 and 2000. In the year 2000, the two main administrative regions of Belgium, Flanders (northern part, $1102 \mathrm{~km}^{2}$ forest according to the Corine Land Cover geodataset of 1990 (European Commission, 1993)) and Wallonia (southern part, $5107 \mathrm{~km}^{2}$ forest according to the same source) carried out a forest inventory, covering together the majority (99.8\%) of the total area under forest in Belgium. In 1984, a first and more extensive forest inventory was already completed for Wallonia.

The three resulting datasets (1984 and 2000 for Wallonia and 2000 for Flanders) were processed by Perrin et al. (2000) and Vande Walle et al. (2005) in order to compute total BOC stocks per sampling plot. The per-plot values were then aggregated for the year 2000 in a spatially implicit approach in order to present total BOC stocks for Belgium (Vande Walle et al., 2005).

The main objective of the present study is to exploit the available forest inventory data for Belgium (Perrin et al., 2000; Vande Walle et al., 2005) in order to examine and attempt to explain the past (1984 and 2000) BOC stocks and stock changes at the level of spatially explicit forested landscape units (LSU), which are defined by a geometric intersection of forest type and soil association maps. The approach we take is an extension of the one developed by Lettens et al. (2004) to assess soil organic carbon stocks and fluxes of agricultural and forested landscape units covering Belgium in a bottom-up approach. The methodology is applied here to the BOC values for 1984 and 2000. We computed the changes in BOC stocks, resulting in $\mathrm{C}$ fluxes, occurring in forested LSU in Wallonia between 1984 and 2000 and estimated total organic carbon (TOC) stocks as the sum of the BOC and SOC stocks per LSU in 2000 for Flanders and Wallonia. In addition we investigated the relationship between the BOC and SOC stock values per LSU in 2000.

\section{MATERIALS AND METHODS}

\subsection{Forest BOC data for 1984 and 2000}

The two main administrative regions in Belgium, Flanders (north) and Wallonia (south) conduct separate forest inventories, but the sampling design and variables are similar (Afdeling Bos and Groen, 2001; Rondeux, 1999; Rondeux et al., 1996). Both inventories are based on a regular sampling grid of $1000 \mathrm{~m} \times 500 \mathrm{~m}$. Each grid intersection that is located in a forest is used as the centre of a sampling plot, which consists of a $1000 \mathrm{~m}^{2}$ circle (radius of $17.84 \mathrm{~m}$ ). In total $2665(21 \%)$ of these sampling plots are situated in Flanders and $9862(79 \%)$ in Wallonia. This 21-to-79 proportion differs slightly from the proportion according to the 1990 Corine Land Cover geodataset (European Commission, 1993) of 18/82 with $1102 \mathrm{~km}^{2}$ of forest in Flanders and $5107 \mathrm{~km}^{2}$ in Wallonia.

The geographic coordinates of the centre point and the forest type are available per plot. The age, stand type, species, trunk circumference at $1.5 \mathrm{~m}$ and total height are recorded for all trees within the sampling circle. The first forest inventory of Wallonia started in 1980 and was completed in 1984, covering all 9862 sampling plots. The second inventory started in 1994 and systematically covers $10 \%$ of the grid points each year. The grid of this second inventory is not exactly the same as the 1984 grid. It has the same spatial resolution but has been shifted diagonally approximately $350 \mathrm{~m}$ southeast. By the year 2001, 6670 points were included in this inventory (Lecomte and Rondeux, 1994). For Flanders, there is only one inventory, which took place between 1997 and 1999 and covered all 2665 Flemish sampling points (Afdeling Bos and Groen, 2001). We assume that the Flemish inventory is representative for the year 2000 and the Walloon inventories are representative for the years 1984 and 2000 respectively. This choice is partly arbitrary but enables the combination of the Walloon and Flemish data into one national forest inventory for 2000. An important difference between the inventories of Flanders and Wallonia is that in Flanders a distinction is made between broadleaf, coniferous and mixed forest, while in Wallonia mixed forest is not recognized. If a forest inventory plot is situated in mixed forest, the sampling point is moved to a homogeneous stand according to predefined rules.

The BOC stock for each sampling plot of the forest inventories has been estimated by Perrin et al. (2000) and Vande Walle et al. (2005) for 1984 and 2000, based on measured solid wood volumes and literature values for wood density, carbon content and biomass expansion factors (BEF), differentiated as much as possible between tree species. Their efforts resulted in a dataset with BOC values expressed in $\mathrm{kg} \mathrm{C} \mathrm{m}{ }^{-2}$ for 9335 sampling points in 2000 and a dataset containing BOC values for 9862 sampling points in 1984. Both datasets were used in the present study.

\subsection{Matching BOC data and landscape units}

By intersecting the Belgian Soil Association map (Tavernier and Maréchal, 1972) (1:500 000) and the 1990 Corine Land Cover geodataset (CLC) (European Commission, 1993) (250 m $\times 250 \mathrm{~m}$ resolution), Belgium is divided into landscape units (LSU) with unique soil and land use type (for detailed description of the LSU, see Lettens et al., 2004). Each LSU is divided over several smaller polygons. The Soil Association map represents broad zones with similar texture and drainage class in 65 soil associations. Climatic stratification, from maritime in the western and northwestern lowlands to semicontinental in the south-eastern plateaus, is an inherent feature of the map. The CLC legend distinguishes between broadleaf, coniferous and mixed forest. The CLC-1990 is used for the BOC stock assessment of both 1984 and 2000. Therefore BOC changes resulting from land use change (afforestation or deforestation) are not explicitly considered. The Walloon forest inventories showed a decrease of $3.6 \%\left(180 \mathrm{~km}^{2}\right)$ of the Walloon forest area between 1984 and 2000 (Perrin et al., 2000), indicating that net land use change in forested areas is limited. According to CLC-1990 and the Belgian Soil Association map, there are 159 forested LSU in Belgium with an average area of $39 \mathrm{~km}^{2}$. All polygons together cover $6222 \mathrm{~km}^{2}$, of which $2000 \mathrm{~km}^{2}$ under broadleaf forest, $1407 \mathrm{~km}^{2}$ under coniferous forest and $2815 \mathrm{~km}^{2}$ under mixed forest. The three forest types do not occur in all possible soil associations. In total 13 of the existing 65 soil associations do not carry any forest.

Punctual biomass measurements can be attributed to landscape units in a process called geomatching (Lettens et al., 2004). Through geomatching, point measurements are attributed to the LSU in which they are geographically situated. This method is not demanding in terms of ancillary information, such as the soil or land use type of 
Table I. Number of observations $n$, average $\left(\mathrm{kg} \mathrm{C} \mathrm{m}^{-2}\right)$ and standard deviation $\left(\mathrm{kg} \mathrm{C} \mathrm{m}^{-2}\right)$ of BOC and SOC stocks (0-100 $\left.\mathrm{cm}\right)$ in the year 2000 for broadleaf, coniferous and mixed forest in Belgium; average TOC stock $\left(\mathrm{kg} \mathrm{C} \mathrm{m}^{-2}\right)$; the proportion BOC and SOC stock relative to TOC $(\%)$ are indicated between brackets.

\begin{tabular}{|c|c|c|c|c|c|c|c|}
\hline \multirow[t]{2}{*}{ Forest type } & \multicolumn{3}{|c|}{ Biomass } & \multicolumn{3}{|c|}{ Soil } & \multirow{2}{*}{$\begin{array}{c}\text { Total } \\
\text { Average OC } \\
\text { stock } \\
\mathrm{kg} \mathrm{C} \mathrm{m}^{-2}\end{array}$} \\
\hline & $n$ & $\begin{array}{c}\text { Average OC } \\
\text { stock } \\
\mathrm{kg} \mathrm{C} \mathrm{m}^{-2}(\%)\end{array}$ & $\begin{array}{l}\text { Standard } \\
\text { deviation } \\
\mathrm{kg} \mathrm{C} \mathrm{m}^{-2}\end{array}$ & $n$ & $\begin{array}{c}\text { Average OC } \\
\text { stock } \\
\mathrm{kg} \mathrm{C} \mathrm{m}^{-2}(\%)\end{array}$ & $\begin{array}{l}\text { Standard } \\
\text { deviation } \\
\mathrm{kg} \mathrm{C} \mathrm{m}^{-2}\end{array}$ & \\
\hline Broadleaf forest & 2046 & $10.0(40)$ & 6.1 & 54 & $14.8(60)$ & 4.6 & 24.8 \\
\hline Coniferous forest & 1596 & $9.5(38)$ & 6.6 & 117 & $15.5(62)$ & 7.4 & 25.0 \\
\hline Mixed forest & 2950 & $8.7(36)$ & 7.0 & 71 & $15.2(64)$ & 11.0 & 23.9 \\
\hline All forests & 6592 & $9.3(38)$ & 6.7 & 242 & $15.2(62)$ & 9.6 & 24.5 \\
\hline
\end{tabular}

the point measurement. Only the geographic coordinates need to be available. In addition, the systematic sampling design of the forest inventories allows the statistically sound assessment of withinand between-LSU variability. LSU for which there are no geomatching forest inventory points available are characterised by the average BOC stock per forest type and region (Flanders or Wallonia). These average values are omitted when computing correlations or significant differences. For 133 of the 159 forested LSU in both Wallonia and Flanders, covering $6204 \mathrm{~km}^{2}$ or $99.7 \%$ of the total considered forest area, a BOC value could be determined using the geomatching procedure with the BOC dataset derived from the year 2000 forest inventory. One hundred and fifteen of the 133 LSU were characterised by more than one inventory point. Of the 9335 sampling points, 6592 (see Tab. I) are used to assess the BOC stocks per LSU. For 1984, 101 LSU (covering $5097 \mathrm{~km}^{2}$ ) and for 2000, $91\left(5084 \mathrm{~km}^{2}\right)$ of the 117 forested LSU in Wallonia (5 $107 \mathrm{~km}^{2}$ according to CLC 1990) could be characterized with an average BOC value through geomatching. The change in BOC stock between 1984 and 2000 could be quantified for $87 \mathrm{LSU}$ or $5080 \mathrm{~km}^{2}$.

The CLC-1990 and the Soil Association map do not provide perfectly homogeneous polygons. Considerable variability exists within the LSU, due to the mapping protocol and because different age classes, site conditions, tree species and management systems occur within one LSU. The geomatching procedure will reflect this withinLSU variability, since forest inventory points within an LSU but with a different forest type may nevertheless match with it. The minimum mapping unit of the CLC is $25 \mathrm{ha}$, smaller forest patches are therefore merged with surrounding non-forest land use types. This is reflected by the fact that for the 2000 inventory, $51 \%$ of the Flemish inventory points are used by geomatching in contrast to $79 \%$ for Wallonia. The average polygon size in Flanders is 26 ha and in Wallonia 41 ha according to CLC-1990.

\subsection{Comparing SOC stocks between LSU in space and time}

The presence of sampling plots which were harvested shortly before the inventory (resulting in $\mathrm{BOC}=0$ ) causes the distribution of the BOC values per LSU to be skewed. Because the distribution was not normal, we adopted the non-parametric Kruskal-Wallis test (Neter et al., 1996) to determine the significance of the factors soil association, forest type and their interaction term in explaining BOC variability. A correction for multiple pairwise testing was applied to test the significance of the differences between factor levels (namely 3 forest types, 52 soil associations and 115 LSU). Since two consecutive inventories are available for the Walloon region, the BOC fluxes per LSU over time can be computed for this region. The statistical significance of the change over time of BOC of LSU, forest types and soil associations is analysed with the Mann-Whitney test (Neter et al., 1996). The significance level $\alpha=0.05$ is then corrected with a Bonferroni correction related to the number of LSU, land use types or soil types that are compared. Since the sampling grid in 2000 has been shifted compared to 1984, the measurements are not paired.

\subsection{Total organic carbon content and $\mathrm{BOC} / \mathrm{SOC}$ ratio per LSU}

In addition to the per-LSU BOC stocks as computed in this paper, per-LSU SOC stocks are available from previous research (Lettens et al., 2005a). By summing the LSU-specific average biomass and soil organic carbon contents, the total organic carbon (TOC, $\mathrm{kg} \mathrm{C}$ $\mathrm{m}^{-2}$ ) content is obtained. This value quantifies the relative contribution of biomass and soil to the total $\mathrm{C}$ stock of the forested LSU. BOC and SOC stocks were available for 77 forested LSU or $91 \%$ of the forested area. For the remaining $82 \mathrm{LSU}$, no field data were available for either BOC or SOC and the average values per forest type and region were used. Since SOC stocks are expected to be higher under forests with more BOC, the correlation between BOC and SOC stocks per LSU is investigated by means of the Spearman Rank correlation coefficient (Neter et al., 1996). Only the 77 LSU for which both BOC and SOC stocks could be computed based on field data were used in this exercise. Both the SOC stocks of the upper $20 \mathrm{~cm}$, upper $100 \mathrm{~cm}$ and the SOC stocks of ectorganic horizons $(\mathrm{EOH}$, i.e. the surface horizons with an organic matter content of at least 30\%) were considered.

\section{RESULTS}

\subsection{BOC stocks in Belgian forests in the year 2000}

The non-parametric analysis shows that the factors forest type, soil association and their interaction term all contribute significantly $(P<0.0001)$ to explain the variability of BOC. However, the multiple comparison test shows that only 54 of the 6555 possible pair-wise comparisons of the 115 LSU that are characterised by more than 1 field observation are mutually significantly different. BOC content of LSU is considerably variable with standard errors ranging between $0.2-6.9 \mathrm{~kg}$ $\mathrm{C} \mathrm{m}^{-2}$ (90\% are lower than 2). BOC stocks are mutually significantly different for 46 of the 1326 soil association pairs in 


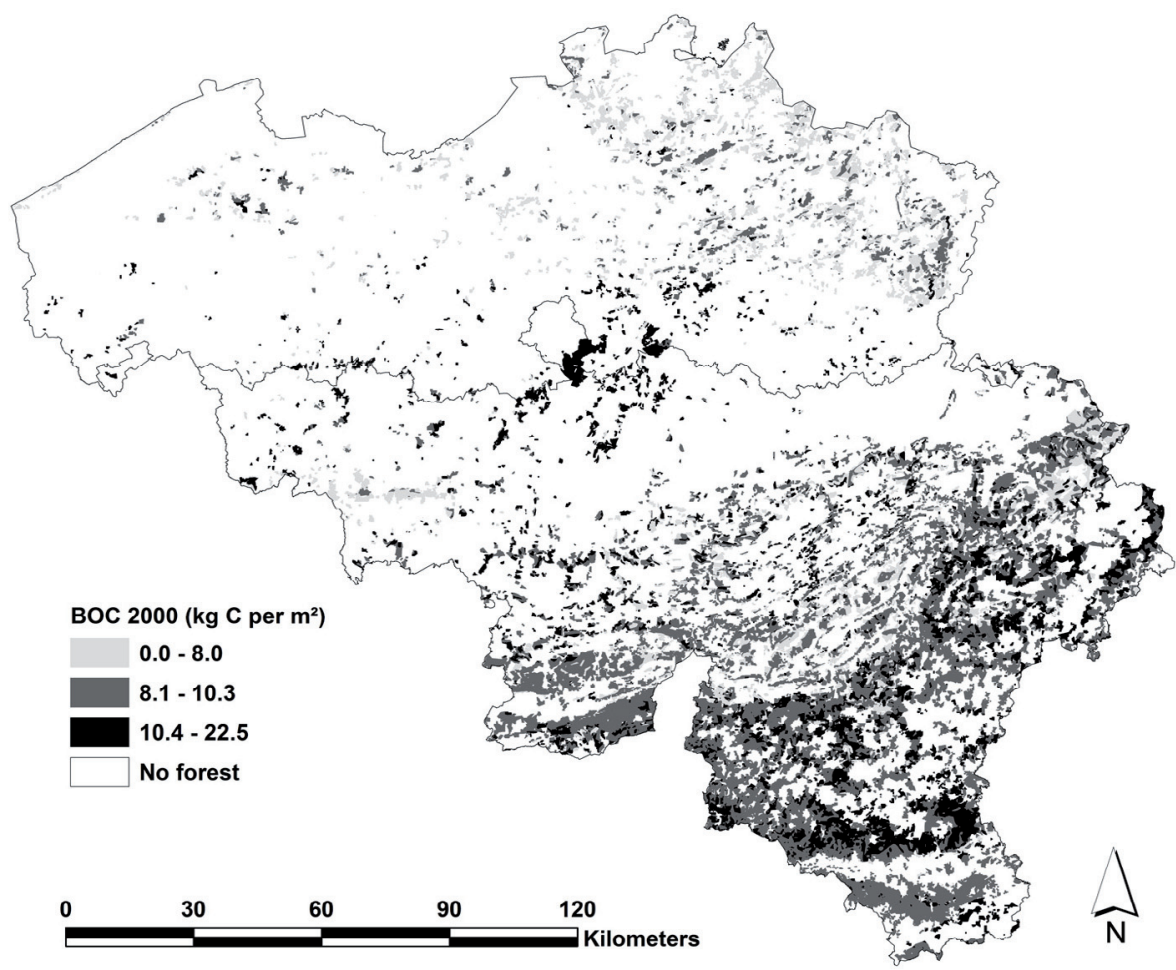

Figure 1. Spatial distribution of BOC stock $\left(\mathrm{kg} \mathrm{C} \mathrm{m}^{-2}\right)$ in Belgian forests in the year 2000. The polygons are the forested LSU for which we found matching forest inventory points.

2000. The highest BOC stocks occur on the fertile deep loam or sandy loam soils of central Belgium. Low BOC stocks occur on dune soils, peat soils and wet sandy soils. Broadleaf forest contains the largest stocks of BOC $\left(10.0 \mathrm{~kg} \mathrm{C} \mathrm{m}^{-2}\right.$ with a $95 \%$ confidence interval of $0.3 \mathrm{~kg} \mathrm{C} \mathrm{m}^{-2}$ ) in 2000 , followed by coniferous forest $\left(9.5 \pm 0.3 \mathrm{~kg} \mathrm{C} \mathrm{m}^{-2}\right)$ and mixed forest $\left(8.7 \pm 0.3 \mathrm{~kg} \mathrm{C} \mathrm{m}^{-2}\right)$ (Tab. I). BOC of the mixed forest type is significantly lower than the two other forest types, which do not differ significantly from each other. The average BOC stock in Flanders $\left(8.5 \pm 0.3 \mathrm{~kg} \mathrm{C} \mathrm{m}^{-2}\right)$ is smaller than in Wallonia $\left(9.5 \pm 0.2 \mathrm{~kg} \mathrm{C} \mathrm{m}^{-2}\right)$ (Fig. 1). Especially coniferous forests contain more BOC in Wallonia (10.3 $\mathrm{kg} \mathrm{C} \mathrm{m}^{-2}$ in 2000) than in Flanders (7.8 $\mathrm{kg} \mathrm{C} \mathrm{m}^{-2}$ ) (Fig. 2).

The total BOC stock in 2000 in Belgian forests as spatially delineated by CLC-1990 amounts to $57.8 \pm 1.0 \mathrm{Mt} \mathrm{C}$ in $6222 \mathrm{~km}^{2}$. Broadleaf forests store $19.9 \pm 0.5 \mathrm{MtC}\left(2000 \mathrm{~km}^{2}\right)$, coniferous forests $13.4 \pm 0.5 \mathrm{Mt} \mathrm{C}\left(1407 \mathrm{~km}^{2}\right)$ and mixed forests the remaining $24.5 \pm 0.7 \mathrm{Mt} \mathrm{C}\left(2815 \mathrm{~km}^{2}\right)$. Forests in Flanders store $9.4 \pm 0.3 \mathrm{MtC}$ (in $1102 \mathrm{~km}^{2}$ ) and in Wallonia $48.4 \pm 0.9 \mathrm{Mt} \mathrm{C}\left(\right.$ in $\left.5107 \mathrm{~km}^{2}\right)$.

\subsection{BOC stocks and fluxes of the Walloon forests for the period 1984-2000.}

The change in BOC stock between 1984 and 2000 amounts to $5.7 \mathrm{Mt} \mathrm{C}$ in $5080 \mathrm{~km}^{2}$, from $42.8( \pm 0.8) \mathrm{Mt} \mathrm{C}$ in 1984 to $48.5( \pm 1.0)$ Mt $\mathrm{C}$ in 2000 . This increase is statistically significant and incurs a sequestration of $0.07 \mathrm{~kg} \mathrm{C} \mathrm{m}^{-2} \mathrm{y}^{-1}$.

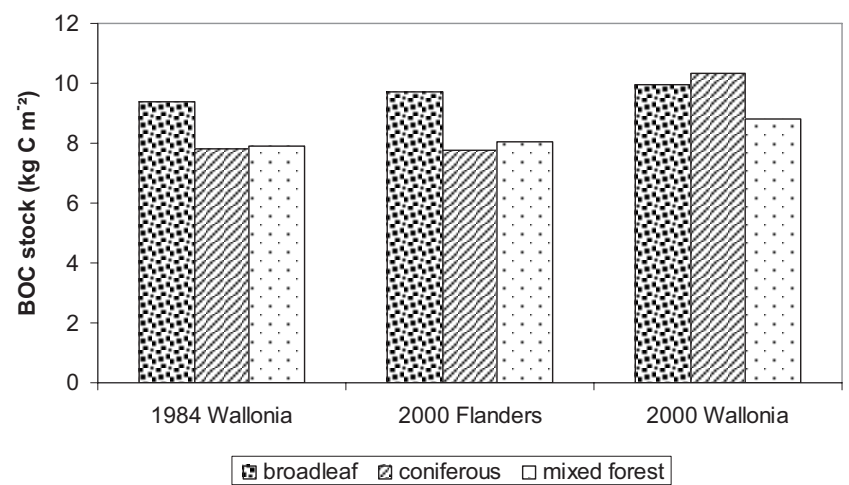

Figure 2. Average BOC stock $\left(\mathrm{kg} \mathrm{C} \mathrm{m}^{-2}\right)$ for broadleaf, coniferous and mixed forest in 1984 and 2000 for the regions Flanders and Wallonia.

Table II contains the BOC stock change of the three forest types between 1984 and 2000. BOC stock of broadleaf forest increased with $7 \%\left(0.04 \mathrm{~kg} \mathrm{C} \mathrm{m}^{-2} \mathrm{y}^{-1}\right)$, coniferous forest with $33 \%\left(0.16 \mathrm{~kg} \mathrm{C} \mathrm{m}^{-2} \mathrm{y}^{-1}\right)$ and mixed forest with $11 \%$ $\left(0.05 \mathrm{~kg} \mathrm{C} \mathrm{m}^{-2} \mathrm{y}^{-1}\right)$. The Mann-Whitney test shows that these increases are all significant. In total 65 of the 87 considered forested LSU of Wallonia increased their BOC stock between 1984 and 2000, but only four of them (together 17\% of the total surface) did so significantly based on the Mann-Whitney test. BOC decreased for 22 LSU but none of these decreases were significant. An increased BOC content is observed for 
Table II. Area $\left(\mathrm{km}^{2}\right)$ derived from CLC-1990, number of forest inventory plots $n$, average BOC stock $\left(\mathrm{kg} \mathrm{C} \mathrm{m}^{-2}\right)$ and standard deviation ( $\mathrm{kg}$ C $\mathrm{m}^{-2}$ ) per forest type in Wallonia for the years 1984 and 2000.

\begin{tabular}{|c|c|c|c|c|c|c|c|}
\hline \multirow[b]{2}{*}{ Forest type } & \multirow{2}{*}{$\begin{array}{l}\text { Area } \\
\mathrm{km}^{2}\end{array}$} & \multicolumn{3}{|c|}{1984} & \multicolumn{3}{|c|}{2000} \\
\hline & & $n$ & $\begin{array}{c}\text { Average } \\
\text { BOC } \\
\mathrm{kg} \mathrm{C} \mathrm{m}^{-2}\end{array}$ & $\begin{array}{l}\text { Standard } \\
\text { deviation } \\
\mathrm{kg} \mathrm{C} \mathrm{m}^{-2}\end{array}$ & $n$ & $\begin{array}{c}\text { Average } \\
\text { BOC } \\
\mathrm{kg} \mathrm{C} \mathrm{m}^{-2}\end{array}$ & $\begin{array}{c}\text { Standard } \\
\text { deviation } \\
\mathrm{kg} \mathrm{C} \mathrm{m}^{-2}\end{array}$ \\
\hline Broadleaf forest & 1683 & 2551 & 9.3 & 6.0 & 1705 & 10.0 & 6.0 \\
\hline Coniferous forest & 972 & 1596 & 7.8 & 7.2 & 1051 & 10.4 & 7.5 \\
\hline Mixed forest & 2452 & 3659 & 7.9 & 7.1 & 2489 & 8.8 & 7.3 \\
\hline All Walloon forests & 5107 & 7806 & 8.4 & 6.7 & 5245 & 9.5 & 7.0 \\
\hline
\end{tabular}

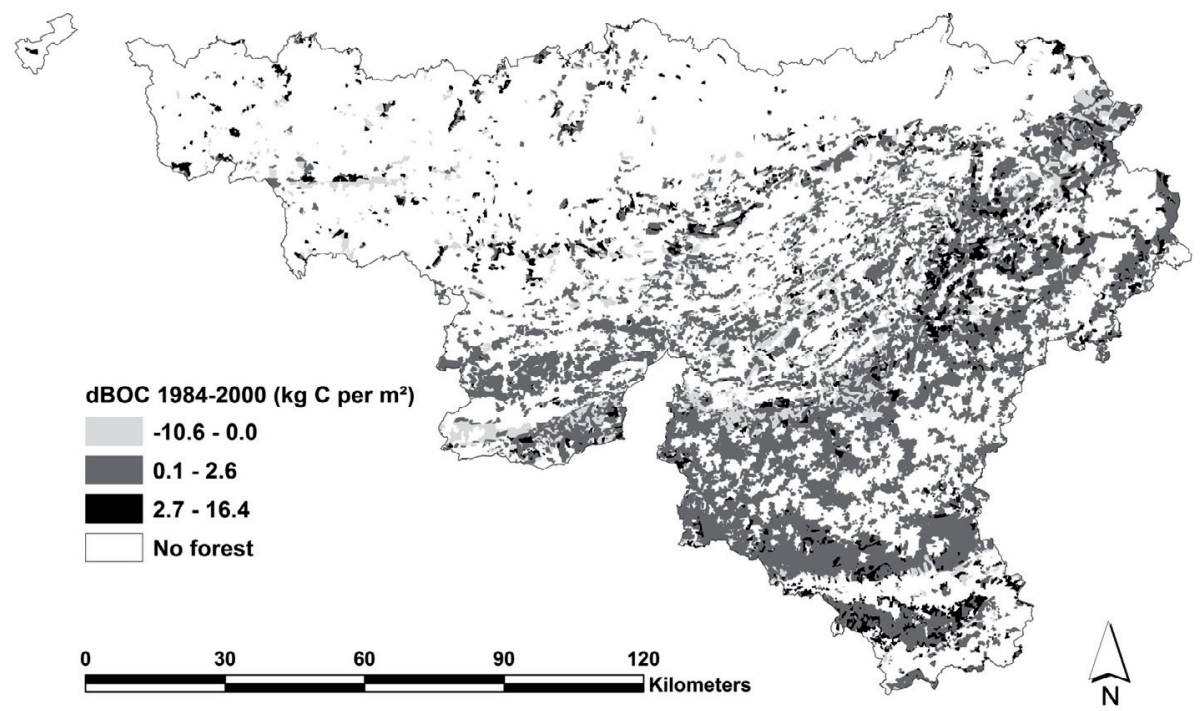

Figure 3. Spatial distribution of BOC stock change $\left(\mathrm{kg} \mathrm{C} \mathrm{m}^{-2}\right)$ in forested LSU of Wallonia between 1984 and 2000. Negative values indicate $\mathrm{C}$ sequestration in forest biomass, positive values indicate $\mathrm{C}$ emissions.

33 of the 41 soil associations. The increase is significant for three associations, incurring sequestration rates between 1.1 and $2.0 \mathrm{~kg} \mathrm{C} \mathrm{m}^{-2}$. Moderate sequestration rates occur in central Wallonia (1.0-1.2 $\left.\mathrm{kg} \mathrm{C} \mathrm{m}^{-2}\right)$. High, but non-significant BOC changes are observed in the most southern tip of Belgium and in north and northeast Wallonia $\left(1.6-2.1 \mathrm{~kg} \mathrm{C} \mathrm{m}^{-2}\right)$ (Fig. 3).

\subsection{TOC stock and BOC/SOC ratio of Belgian forest in 2000}

Broadleaf forest has the highest BOC stock in combination with the lowest SOC stock $(0-100 \mathrm{~cm})$ in 2000 , so the average TOC stock $\left(24.8 \mathrm{~kg} \mathrm{C} \mathrm{m}^{-2}\right)$ is close to the value for coniferous forest $\left(25.0 \mathrm{~kg} \mathrm{C} \mathrm{m}^{-2}\right)$, with high $\mathrm{C}$ stocks in the soil compartment (Tab. I). Mixed forest with low BOC stocks and moderate SOC stocks has the lowest TOC value $(23.9 \mathrm{~kg} \mathrm{C}$ $\mathrm{m}^{-2}$ ). The TOC stock stored in forested LSU in the year 2000 equals 152.2 Mt C of which 49.1 Mt C resides in broadleaf forest, $34.8 \mathrm{Mt} \mathrm{C}$ in coniferous forest and 68.3 Mt $\mathrm{C}$ in mixed forest. Proportionally, between 36 and $40 \%$ of the OC is stored in biomass and between 63 and $59 \%$ in the upper $100 \mathrm{~cm}$ of soil. Estimates of ectorganic horizons were not considered in the TOC computation, since measurements are not available for all LSU for all considered years.

For SOC stocks in the 0-100 cm layer, the Spearman Rank correlation coefficient is not significantly different from zero $(P=0.3)$. When considering SOC in the upper $20 \mathrm{~cm}$ only, a weak positive correlation of 0.18 is found approaching statistical significance $(P=0.1)$. Data on ectorganic horizons are available for Flanders only. BOC stocks of LSU are negatively correlated with $\mathrm{OC}$ stocks of EOH in Flanders $(P=0.01$, $R=-0.48$ ) (Fig. 4a). The correlation between BOC and SOC (upper $20 \mathrm{~cm}$ ) and BOC and ectorganic $\mathrm{C}$ is also computed for the individual forest inventory points in Flanders, where BOC, SOC and litter layer have all been measured (126 forest inventory points in total). Neither of the variable pairs is significantly correlated $(P=0.9$ for $0-20 \mathrm{~cm}$ SOC versus BOC and 0.4 for $\mathrm{OC}$ in ectorganic layers versus BOC). However, Fig. 4b shows that very high BOC stocks do not occur concurrently with very high $\mathrm{OC}$ stocks in the ectorganic horizons. 

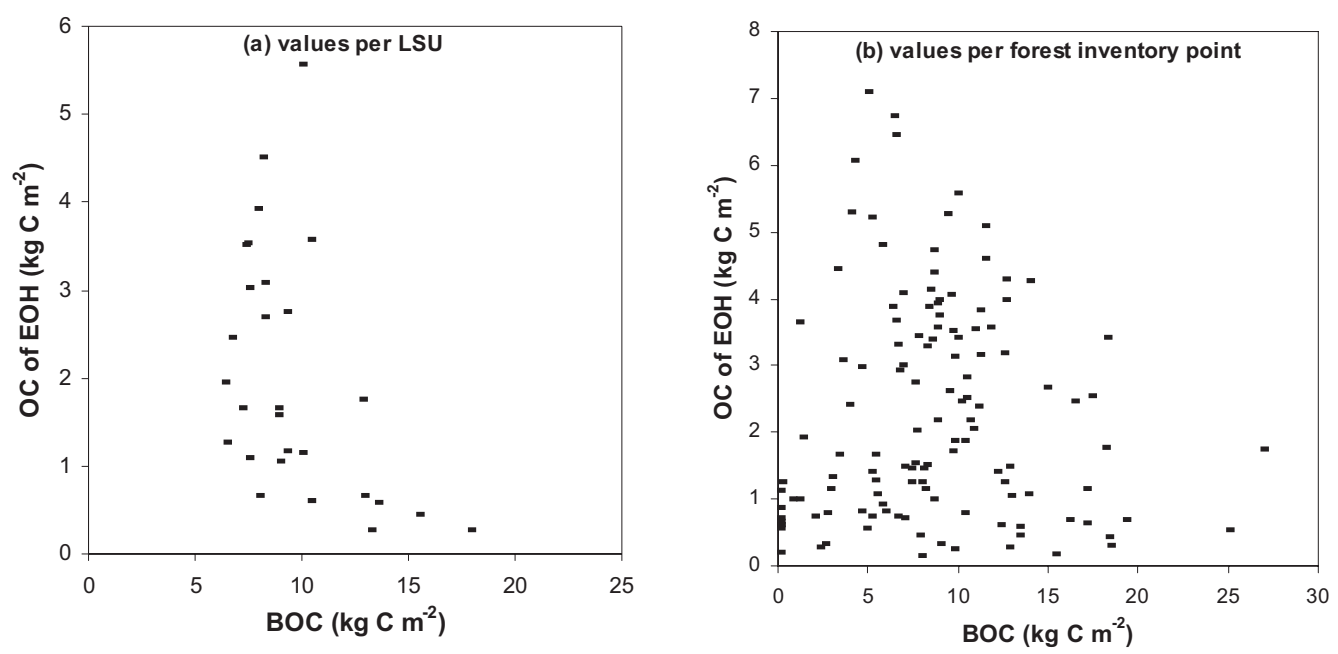

Figure 4. BOC stock $\left(\mathrm{kg} \mathrm{C} \mathrm{m}^{-2}\right)$ versus OC stock in the ectorganic layers $\left(\mathrm{kg} \mathrm{C} \mathrm{m}^{-2}\right)$ of $\mathrm{LSU}(\mathrm{a})$; BOC stock versus OC stock in the ectorganic horizons $(\mathrm{EOH})$ of forest inventory points in Flanders (b).

\section{DISCUSSION}

\subsection{BOC stocks of the Belgian forests in 2000}

We chose the spatially explicit approach because it is a highly flexible and broadly applicable approach. If several datasets are available, for instance from private and public sectors, or for agricultural land and forest, they can easily be combined per LSU in the geomatching approach. Data on other site characteristics (e.g. soil OC) or predictions of future BOC stocks, possibly based on a different sampling design, can be linked to the BOC results as well. The influence of the site factors land use and soil type can be directly assessed and maps can be drawn to illustrate spatial patterns. The proposed approach could be applied to other countries, insofar that they dispose of the necessary high-resolution spatial datasets. The quality of the spatial datasets will determine the level of precision of the BOC estimate. Depending on the research questions, the LSU can be more general (e.g. by using only soil texture instead of soil association) or more detailed (e.g. including management or forest age). For prediction of future BOC changes, information on climate could be included as well, especially for large countries. We did not explicitly divide the LSU in climatic zones, but the Soil Association map inherently includes climate stratification.

Our estimates compare relatively well with the previous estimate by Vande Walle et al. (2005). They compute a total BOC stock of 60.9 (42.8-83.5) Mt C for Belgium in 2000, with 12.3 (8.7-18.6) Mt C of this total stock stored in Flanders and 48.6 (34.1-64.9) Mt C in Wallonia. The current paper presents a stock of $57.8 \mathrm{Mt} \mathrm{C}$ in Belgian forests, divided over 9.4 Mt C in Flanders and 48.4 Mt C in Wallonia. The average per ha BOC stock for Flanders according to Vande Walle et al. (2005) is $8.5 \mathrm{~kg} \mathrm{C} \mathrm{m}^{-2}$ and for Wallonia $10.6 \mathrm{~kg} \mathrm{C} \mathrm{m}^{-2}$. The latter value is slightly higher than the value of $9.5 \mathrm{~kg} \mathrm{C} \mathrm{m}^{-2}$ presented here (Tab. II). The higher estimate of forest area in
Flanders of Vandewalle et al. (2005) (1447 km²), based not on aerial photography, but on the sampling grid itself, could explain their higher total $\mathrm{C}$ stock in this region. The higher perha BOC stock for Wallonia may be due to the different general approach for upscaling the forest inventory BOC data or to smaller computational differences, such as the fact that they used an earlier version of the Walloon inventory, with only 5500 points instead of our 6670 points, or the fact that they have used median values where we used averages. Since $21 \%$ of the Walloon forest inventory points have a BOC value of 0 (recently harvested sites or young plantations), average BOC values tend to be lower than median values.

The results we present here are higher than the results for neighbouring countries. Dutch forests, consisting mainly of Scots pine on poor sandy soils, contain on average $5.9 \mathrm{~kg} \mathrm{C}$ $\mathrm{m}^{-2}$ in 1990 (Nabuurs and Mohren, 1993). However, the older Beech stands on the more fertile soils of the Netherlands contain on average more than twice this amount, namely $12.4 \mathrm{~kg}$ $\mathrm{C} \mathrm{m}^{-2}$. Similar high stocks in old broadleaf forest were computed by Lecointe et al. (2006) in old French Beech forests $\left(11.3 \mathrm{~kg} / \mathrm{m}^{2}\right)$ and by Balboa-Murias et al. (2006) for old oak stands in Spain $\left(15.0 \mathrm{~kg} / \mathrm{m}^{2}\right)$. In Great Britain, broadleaf forest stores $5.9 \mathrm{~kg} \mathrm{C} \mathrm{m}^{-2}$, coniferous forest $2.1 \mathrm{~kg} \mathrm{C} \mathrm{m}^{-2}$ and mixed forest $4.3 \mathrm{~kg} \mathrm{C} \mathrm{m}^{-2}$ in 1990 (Milne and Brown, 1997). These low values for coniferous forest are explained by the young age (Milne and Brown, 1996) and by the fact that the authors did not include $\mathrm{C}$ in foliage and fine roots. The BOC stocks of $10.3 \mathrm{~kg} \mathrm{C} \mathrm{m}^{-2}$ of the German forests (Baritz and Strich, 2000) and of $8.2 \mathrm{~kg} \mathrm{C} \mathrm{m}^{-2}$ of the Austrian forests (Weiss and Schlamadinger, 2000) are closer to our values for Belgium. At the European level, de Vries et al. (2003) found an average BOC stock of $10.0 \mathrm{~kg} \mathrm{C} \mathrm{m}^{-2}$ in broadleaf forest, $6.4 \mathrm{~kg} \mathrm{C} \mathrm{m}^{-2}$ in coniferous forest and $8.2 \mathrm{~kg} \mathrm{C} \mathrm{m}^{-2}$ in mixed forest. Brown et al. (1999) found that the forests of the eastern US represent a pool of $15.9 \mathrm{~kg} \mathrm{C} \mathrm{m}^{-2}$ on average in hardwood and $11.0 \mathrm{~kg}$ $\mathrm{C} \mathrm{m}^{-2}$ in softwood forests. 


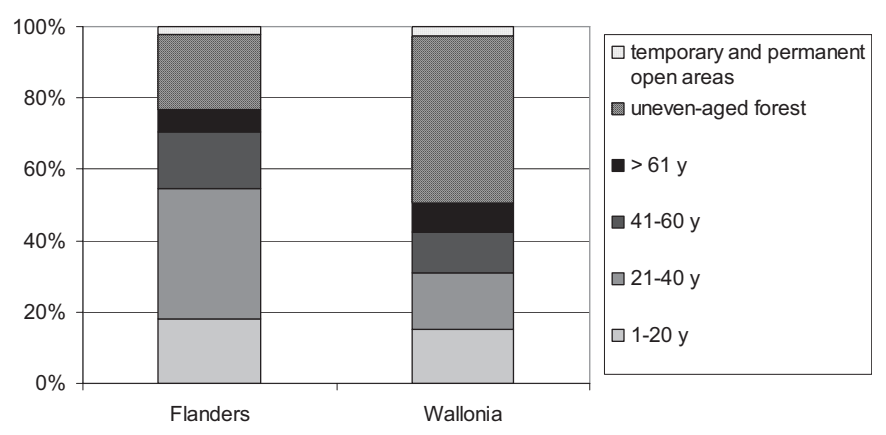

Figure 5. Forest age class distribution for Flanders and Wallonia.

The average BOC stocks of 2000 reflect the site quality (Fig. 1). Low BOC stocks occur on nutrient poor and relatively dry sandy soils of northern Belgium (with yearly rainfall around $800 \mathrm{~mm}$ ) and on organic soils in Wallonia. High BOC stocks appear in broadleaf forests on deep and nutrient rich loam and sandloam soils in central Belgium and on stony loam soils of south Wallonia, where yearly rainfall reaches $1400 \mathrm{~mm}$ in the highest parts. The very high and very low BOC stocks occur mostly in broadleaf forest and occasionally in mixed forest. BOC stocks in coniferous forest are more in the intermediate range. Nevertheless the difference in BOC stocks between Flanders and Wallonia is most pronounced in coniferous forest. For Flanders, where Scots pine is the most common conifer, the BOC content is considerably lower than for Wallonia, where Spruce dominates. For a country of rather modest size such as Belgium, forest age may also play a role in total BOC stocks. The age structure of Belgian forests shows that forest stands in Flanders, with 55\% younger than 40 years, are on average younger than in Wallonia, with $31 \%$ younger than 40 years (Afdeling Bos and Groen, 2001) (Fig. 5). The lower average age and site quality could explain the lower BOC content of Flemish forests.

\subsection{BOC and SOC fluxes between 1984 and 2000}

In 1984, coniferous and mixed forests show comparable BOC stock values, which are significantly lower than the BOC stocks for broadleaf forests. Due to high sequestration rates between 1984 and 2000, coniferous forest stores the largest amount of BOC of all forest types in 2000 (Tab. II). Sequestration rates per soil type are variable. High sequestration rates occur on some stony loam and moderately dry loam soils of northern Wallonia and on clay soils of the most southern tip of Belgium. C losses occur infrequently throughout Wallonia, but often in more northern associations, which are in fact underrepresented by the point measurements of the Walloon inventories.

Part of the overall sequestration that is observed between 1984 and 2000 is most likely due to the increasing average age of forests (Barford et al., 2001). The average carbon stock in biomass per hectare for a certain age class has increased as well, due to high forest productivity during recent years in Belgium (Laitat et al., 2004; Perrin et al., 2000). The fact that we found such a large BOC increase in coniferous forests may partly be due to the sampling protocol in 1984 , when $28 \%$ of the plots had a BOC stock equal to zero in 1984, compared to $21 \%$ in 2000. This has enhanced the BOC increase per hectare. All inventories took place over several years. The 1984 and 2000 Walloon inventories lasted 4 and 7 years respectively. This range introduces an error when estimating average yearly fluxes. Nevertheless, our results compare well with most literature values. Nabuurs et al. (2003) model BOC sequestration in Europe of $0.084 \mathrm{~kg} \mathrm{C} \mathrm{m}^{-2} \mathrm{y}^{-1}$ in the period 1981-1999 and $0.098 \mathrm{~kg} \mathrm{C} \mathrm{m}^{-2} \mathrm{y}^{-1}$ in 1990-1999. Liski et al. (2002) based their estimations on forest inventory data of western European countries carried out between 1950 and 1990. The estimated sequestration amounted to $0.039 \mathrm{~kg} \mathrm{C} \mathrm{m}^{-2} \mathrm{y}^{-1}$ during the $90 \mathrm{~s}$. The results of De Vries et al. (2003) for European forests are based upon repeated measurements with a five year interval. The forest biomass of the selected plots sequestered $0.22 \mathrm{~kg}$ $\mathrm{C} \mathrm{m}^{-2} \mathrm{y}^{-1}$ in the 1990s. Liski et al. (2006) modelled a slower sequestration rate in Finnish forests of $0.028 \mathrm{~kg} \mathrm{C} \mathrm{m}^{-2} \mathrm{y}^{-1}$ during the 1990s. They attributed this trend mainly to increased $\mathrm{C}$ density of the Finnish forests. Barford et al. (2001) measured $\mathrm{C}$ sequestration in a broadleaf forest of eastern USA during eight years by making sequential inventories. They computed a sequestration rate of $0.10( \pm 0.02) \mathrm{kg} \mathrm{C} \mathrm{m}^{-2} \mathrm{y}^{-1}$.

As computed in Lettens et al. (2005b), the average SOC stock of coniferous forest increased from $11.3 \mathrm{~kg} \mathrm{C} \mathrm{m}^{-2}$ to $15.5 \mathrm{~kg} \mathrm{C} \mathrm{m}^{-2}$ over 40 years between 1960 and 2000, incurring a change of $0.10 \mathrm{~kg} \mathrm{C} \mathrm{m}^{-2} \mathrm{y}^{-1}$. For broadleaf forest, a SOC sequestration of $0.14 \mathrm{~kg} \mathrm{C} \mathrm{m}^{-2} \mathrm{y}^{-1}$ is computed and for mixed forest $0.13 \mathrm{~kg} \mathrm{C} \mathrm{m}^{-2} \mathrm{y}^{-1}$. These numbers suggest that carbon has been sequestered at comparable rates in BOC and SOC pools over the past two decades.

\subsection{TOC stocks and $\mathrm{BOC} / \mathrm{SOC}$ ratio for Belgian forest in 2000}

The partitioning of TOC in BOC and SOC is relatively similar for the three forest types. Around $40 \%$ of the OC is stored in biomass and the remainder resides in the soil (Tab. I). In our study, peat soils have very high SOC stocks while forest BOC stocks are generally low, leading to exceptionally high SOC $(0-20 \mathrm{~cm})$ /BOC proportion of 1.6-3.6. The spruce production forests on the stony loam soils of Wallonia have high $\mathrm{SOC} / \mathrm{BOC}$ ratios as well. The young pine forests of nutrientpoor soils of northern Belgium, where the lowest productivity rates of Belgium are recorded, show low BOC stocks and low $\mathrm{SOC}$ stocks, resulting in average to low $\mathrm{SOC} / \mathrm{BOC}$ ratios. For the old broadleaf forests on the nutrient-rich loam soils of central Belgium, SOC/BOC equals 0.5 only. These forests contain very high $\mathrm{BOC}$ in combination with moderate SOC stocks.

With primary production as the main source of organic carbon for forest soils, the magnitude of BOC and SOC stocks are expected to be positively correlated. However, this does not appear from our data. For the 28 Flemish LSU, we found a weak negative correlation between the BOC stocks and OC stocks of ectorganic horizons of LSU (Fig. 4a). Forests with very high BOC stocks have low stocks of $\mathrm{C}$ in their ectorganic 
horizons. These are mostly broadleaf forest on the loam soils of central Belgium. For forests with moderate or low BOC values, a large variation in EOH-C stocks is observed, with high $\mathrm{EOH} \mathrm{C-stocks} \mathrm{under} \mathrm{coniferous} \mathrm{forest} \mathrm{and} \mathrm{low} \mathrm{stocks}$ under broadleaf forest. Very similar results are obtained when comparing BOC and SOC stocks of individual forest inventory points in Flanders (Fig. 4b). The main difference between these two figures is the presence of more extreme observations (with very high or very low BOC stocks) in Figure 4b.

\section{CONCLUSION}

BOC stocks computed for points in the forest inventories of the years 1984 and 2000 were upscaled to spatially explicit forested landscape units by means of the geomatching approach. This novel approach was compared with a spatially implicit BOC inventory using the same forest inventory data but delivering spatially aggregated results only. Whereas the overall and per-forest type stocks are comparable, it was shown that the adopted approach has the advantage of taking into account the natural variability of the forests and further enables the computation of BOC stock changes of Walloon forests between 1984 and 2000, even though a different sampling grid was used.

We found that the highest per ha stocks resides in broadleaf forest and the lowest in mixed forest. Forest in Flanders contains on average less BOC than in Wallonia and this may be explained by the lower average forest age and lower site quality in Flanders. The average BOC and SOC stocks in 2000 per forested LSU are only weakly correlated and BOC/SOC ratios vary strongly between LSU. Comparison of the average yearly BOC fluxes with soil organic carbon fluxes for the same LSU showed that Walloon forests have sequestered C in biomass and soil at comparable rates. To explain the observed sequestration, it was hypothesised that forest management, and more specifically increasing average forest age have played an important role. Insofar that increasing average age causes the $\mathrm{C}$ sequestration, it may be expected that Belgian forests may continue to sequester $\mathrm{C}$ for a limited period of time in the future. Other effects, such as atmospheric $\mathrm{N}$ fertilization and increasing atmospheric $\mathrm{CO}_{2}$ concentration, may have played a role as well and deserve further investigation, especially for the prediction of future BOC changes. The influence of recent afforestation or deforestation activities could also influence BOC fluxes. Since a CLC geodataset is now available for the year 2000 and upcoming for the year 2006, there is potential for future studies to better quantify these changes.

Acknowledgements: This research has been performed in the framework of the METAGE-project (EV/01/14), financed by the Belgian Federal Science Policy, whom we gratefully acknowledge for their financial support. We would like to thank the forest administrations of Flanders (MVG-LNE Afdeling Natuur en Bos) and Wallonia (DGRNE, Division de la Nature et des Forêts) for supplying the necessary data.

\section{REFERENCES}

Afdeling Bos and Groen, 2001. De bosinventarisatie van het Vlaamse Gewest, Resultaten van de eerste inventarisatie 1997-1999. Report of the Ministerie van de Vlaamse Gemeenschap, Brussel.

Balboa-Murias M.A., Rojo A., Alvarez J.G., and Merino A., 2006. Carbon and nutrient stocks in mature Quercus robur L. stands in NW Spain. Ann. For. Sci. 63: 557-565.

Barford C.C., Wofsy S.C., Goulden M.L., Munger J.W., Pyle E.H., Urbanski S.P., Hutyra L., Saleska S.R., Fitzjarrald D., and Moore K., 2001. Factors controlling long- and short-term sequestration of atmospheric $\mathrm{CO}_{2}$ in a mid-latitude forest. Science 294: 1688-1691.

Baritz R. and Strich S., 2000. Forests and the National Greenhouse Gas Inventory of Germany, Biotechnol. Agron. Soc. Environ. 4: 267-271.

Brown S.L., Schroeder P., and Kern J.S., 1999. Spatial distribution of biomass in forests of the eastern USA. For. Ecol. Manage. 123: 81-90.

De Vries W., Reinds G.J., Posch M., Sanz M.J., Kranse G.H.M., Catalayud V., Renaud J.P., Dupouey J.L., Sterba H., Vel E., Dobbertin M., Gundersen P., and Voogd J.C.H., 2003. Intensive monitoring of forest ecosystems in Europe, Technical Report 2003, Forest Intensive Monitoring Coordinating Institute, EC-UN/ECE, Brussels, Geneva.

European Commission, 1993. Corine land cover, technical guide EUR 12585, Directorate-General Environment, Nuclear Safety and Civil Protection, Luxembourg.

Grace J., 2004. Understanding and managing the global carbon cycle. J. Ecol. 92: 189-202.

Houghton R., 2003. Revised estimates of the annual net flux of carbon to the atmosphere from changes in land use and land management 1850-2000. Tellus 55B: 378-390.

IPCC, 2000. A special report of the IPCC. Land use, land-use change, and forestry, Cambridge University Press.

Janssens I.A., Freibauer A., Ciais P., Smith P., Nabuurs G.J., Folberth G., Schlamadinger B., Hutjes R.W.A., Ceulemans R., Schulze E.D., Valentini R., and Dolman A.J., 2003. Europe's terrestrial biosphere absorbs 7 to $12 \%$ of European anthropogenic $\mathrm{CO}_{2}$ emissions. Science 300: 1538-1542.

Laitat E., Perrin D., Sheridan M., Lebegue C., and Pissart G., 2004. EFOBEL un modèle de calcul de la séquestration du carbone par les forêts, selon les termes des accords de Marrakech et les engagements de rapportage de la Belgique au Protocole de Kyoto. Biotechnol. Agron. Soc. Environ. 8: 27-40.

Lecointe S., Nys C., Walter C., Forgeard F., Huet S., Recena P., and Follain S., 2006. Estimation of carbon stocks in a beech forest (Fougères Forest - W. France) : extrapolation from the plots to the whole forest. Ann. For. Sci. 63, 139-148.

Lecomte H. and Rondeux J., 1994. L'inventaire forestier régional wallon : brève présentation méthodologique. Silva Belgica 101: 9-16.

Lettens S., Van Orshoven J., Van Wesemael B., and Muys B., 2004. Soil organic and inorganic carbon content of landscape units in Belgium for 1950-1970. Soil Use Manage. 20: 40-47.

Lettens S., Van Orshoven J., Van Wesemael B., De Vos B., and Muys B., 2005a. Stocks and fluxes of soil organic carbon for landscape units in Belgium derived from heterogeneous data sets for 1990 and 2000. Geoderma 127: 11-23.

Lettens S., Van Orshoven J., Van Wesemael B., Muys B., and Perrin D., 2005b. Soil organic carbon changes in landscape units of Belgium between 1960 and 2000 with reference to 1990. Glob. Change Biol. 11: $2128-2140$.

Liski J., Perruchoud D., and Karjalainen T., 2002. Increasing carbon stocks in the forest soils of Western Europe. For. Ecol. Manage. 169: 159-175. 
Liski J., Lehtonen A., Palosuo T., Peltoniemi M., Eggers T., Muukkonen P., and Makipaa R., 2006. Carbon Accumulation in Finland's Forests 1922-2004 - an estimate obtained by combination of forest inventory data with modelling of biomass, litter and soil. Ann. For. Sci. 63 : 687-697.

Milne R. and Brown T.A., 1997. Carbon in the vegetation and soils of Great Britain, J. Environ. Manage. 49: 413-433.

Nabuurs G.J. and Mohren G.M.J., 1993. Carbon in Dutch forest ecosystems, Neth. J. Agr. Sci. 41: 309-326.

Nabuurs G.J., Schelhaas M.J., Mohren G.M.J., and Field C.B., 2003. Temporal evolution of the European forest sector carbon sink from 1950 to 1999. Glob. Change Biol. 9: 152-160.

Neter J., Kutner M.H., Nachtsheim C.J., and Wasserman W., 1996. Applied linear statistical models, The McGraw-Hill Companies, Inc.

Perrin D., Temmerman M., and Laitat E., 2000. Calculation on the impacts of forestation, afforestation and reforestation on the Csequestration potential in Belgian forest ecosystems. Biotechnol. Agron. Soc. Environ. 4: 259-262.

Prentice I.C., Farquhar G., Fasham M.J.R., Goulden M.L., Heimann M., Jaramillo V.J., Kheshgi H.S., Le Quéré C., Scholes R.J., and Wallace D.W.R., 2001. The carbon cycle and atmospheric carbon dioxide. In: Houghton J.T., Ding Y., Griggs D.J., Noguer M., van der Linden P.J., and Xiaosu D. (Eds.), Climate change 2001, the scientific basis, Cambridge University Press, Cambridge, UK, pp. 185-237.

Rondeux J., 1999. La mesure des arbres et des peuplements forestiers, Gembloux, Les Presses Agronomiques de Gembloux (Belgium), $521 \mathrm{p}$.
Rondeux J., Lecomte H., Florkin P., and Thirion M., 1996. L'inventaire permanent des ressources ligneuses de la Région Wallonne: principaux aspects méthodologiques, Les cahiers forestiers gembloutois, Faculté Universitaire des Sciences Agronomiques de Gembloux (Belgium), 19 p.

Schimel D., Melillo J., Tian H.Q., Mcguire A.D., Kicklighter D., Kittel T., Rosenbloom N., Running S., Thornton P., Ojima D., Parton W., Kelly R., Sykes M., Neilson R., and Rizzo B., 2000. Contribution of increasing $\mathrm{CO} 2$ and climate to carbon storage by ecosystems in the United States. Science 287: 2004-2006.

Tavernier R. and Maréchal R., 1972. Bodemassociatiekaart 1:500 000. In: Altlas van België, pp. 11A en 11B, Nationaal Geografisch Instituut, Brussel, Belgium.

Vande Walle I., Van Camp N., Perrin D., Lemeur R., Verheyen K., Van Wesemael B., and Laitat E., 2005. Growing stock-based assessment of the carbon stock in the Belgian forest biomass. Ann. For. Sci. 62: 853-864.

Valentini R., Matteucci G., Dolman A.J., Schulze E.D., Rebmann C., Moors E.J., Granier A., Gross P., Jensen N.O., Pilegaard K., Lindroth A., Grelle A., Bernhofer C., Grunwald T., Aubinet M., Ceulemans R., Kowalski A.S., Vesala T., Rannik U., Berbigier P., Loustau D., Guomundsson J., Thorgeirsson H., Ibrom A., Morgenstern K., Clement R., Moncrieff J., Montagnani L., Minerbi S., and Jarvis P.G., 2000. Respiration as the main determinant of carbon balance in European forests. Nature 404: 861-865.

Weiss P. and Schlamadinger B., 2000. Research activities related to the role of forests and forestry in climate change mitigation in Austria, Biotechnol. Agron. Soc. Environ. 4: 252-258. 